\title{
Notes on the genus Lactarius from the Rocky Mountain alpine zone in regard to Finnish arctic- alpine species
}

\author{
CATHY L. CRIPPS and ED BARGE
}

\begin{abstract}
CRIPPS, C. \& BARGE, E. 2013: Notes on the genus Lactarius from the Rocky Mountain alpine zone in regard to Finnish arctic-alpine species . - Karstenia 53: 00-00. HELSINKI. ISSN 0453-3402.

Lactarius is an important ectomycorrhizal genus (Basidiomycota, Russulales) and a subset of species occur in arctic and alpine habitats. These species are well known in Europe, Greenland, Svalbard and Scandinavia; however there is scant information from the Rocky Mountain alpine zone in North America. Here we report five Lactarius species from above $3000 \mathrm{~m}$ at latitude $45^{\circ} \mathrm{N}$ in the northern Rockies and above $3700 \mathrm{~m}$ at latitude $36^{\circ}-38^{\circ} \mathrm{N}$ in the southern Rockies. Lactarius lanceolatus, L. nanus, L. salicis-reticulatae and L. repraesentaneus are reported with Salix species and L. glyciosmus with Betula glandulosa. All have been recorded from Finland at $68^{\circ}-70^{\circ} \mathrm{N}$ at much lower elevations (300-1000 m) in the alpine, subarctic and subtemperate zones.
\end{abstract}

Key words: ectomycorrhizal, North America, Rocky Mountains, Russulales, Salix, arctic-alpine mycology

Cathy L. Cripps \& Ed Barge, Plant Sciences and Plant Pathology Department, Montana State University, Bozeman, MT 59717,U.S.A.; email: ccripps@montana.edu

\section{Introduction}

Lactarius is a diverse genus with over 400 species described worldwide (Verbeken 2001). In the northern hemisphere, Lactarius is ectomycorrhizal and particular species may be restricted to certain host plants (Heilmann-Clausen et al. 1998). A limited number of Lactarius species occur in arctic and alpine habitats in the Northern Hemisphere where they are primarily associated with Salix, Betula and Dryas. Research has shown that shrubs (primarily willows) are expanding their range in arctic and alpine tundra (Sturm et al. 2001). DeSlippe et al. (2011) suggest that increased mycorrhizal diversity and larger mycorrhizal networks may further increase shrub expansion in the arctic, highlighting the importance of ectomycorrhizal fungi in this system. Thus the limited number of ectomycorrhizal fungi (including Lactarius) able to associate with shrubs in cold, harsh environments may become increasingly important as climate change shifts microbial communities (Cripps \& Eddington 2005).

Thirty to forty species of Lactarius have been reported from arctic-alpine habitats in Alaska (Miller et al. 1973, Laursen \& Ammirati 1982, Geml et al. 2009), the Canadian Arctic (Ohenoja 1972, Ohenoja \& Ohenoja 1993, 2010), Greenland (Lange 1955, Knudsen \& Borgen 1982, Borgen et al. 2006), Svalbard (Ohenoja 1971, Gulden \& Torkelsen 1996, Geml et al. 2012), Iceland (Hallgrímsson 1993), Norway (Gulden et al. 1985, Gulden \& Jenssen 1988, Gulden 2005), Sweden (Knudsen \& Vesterholt 2012) Finland (Kallio \& Kankainen 1964, Kallio 
1982, Korhonen 1984, Gulden et al. 1985, Ohenoja 1996, Knudsen \& Vesterholt 2012), the Alps (Favre 1955, Kühner 1975, Bon 1985, Senn-Irlet 1988, Bon 1998, Graf 1994, Jamoni 1995, Kränzlin 2005), the Pyrenees (Corriol 2008), the Carpathians (Ronikier 2008), and the Urals (Knudsen \& Mukhin 1998).

A few papers have addressed other genera from the Rocky Mountain alpine zone south of the Canadian border, including Amanita (Cripps \& Horak 2010), Laccaria (Osmundson et al. 2005), Inocybe (Cripps et al. 2010), Arrhenia (Cripps \& Horak 2006) and Hebeloma (Miller \& Evenson 2001) but none have addressed the genus Lactarius in the North American alpine tundra outside of Alaska, Greenland, and Arctic Canada. In North America, over 200 species of Lactarius have been reported by Hesler \& Smith (1979) but arctic-alpine species were not covered.

Previously, a few Lactarius species were included in checklists from the Rocky Mountain alpine zone (Cripps \& Horak 2008, Cripps \& Ammirati 2010a,b) and here we report actual collection data with ecological notes. Most are the first official reports of these species from the Rocky Mountain alpine zone south of the Canadian border. All of the species reported are known from Finland at lower elevations and comparisons will be made as to ecology. Results from phylogenetic analysis of the internal transcribed spacer (ITS) region of ribosomal DNA and the region between conserved domains 6 and 7 of the nuclear gene encoding the second largest subunit of RNA polymerase II ( $r p b 2)$ are currently being compiled for North American and Eurasian (including some Finnish) collections of the taxa presented in this paper. This article is part of the proceedings of the $9^{\text {th }}$ International Symposium of Arctic and Alpine Mycology (ISAM) held at Kevo Subarctic Research Station in Inari Lapland, Finland, 26.08. - 01.09.2012.

\section{Material and methods}

In North America the Rocky Mountains extend from New Mexico to Alaska and consists of widely dispersed fragmented islands of alpine tundra on mountain tops. In this study, all sites are south of the U.S.A. - Canadian border (Fig. 1). The study sites in the north-central Rocky Mountains are on the Beartooth Plateau above treeline at $3000 \mathrm{~m}$ a.s.l. and extend along the Montana/Wyoming border at latitude $45^{\circ} \mathrm{N}$ (Fig. 2). The plateau is comprised of a mosaic of meadows, wetlands and talus fields with predominantly granite-derived soils (Johnson \& Billings 1962). The southern Rocky Mountain sites sit above the treeline at $3700 \mathrm{~m}$ a.s.l. in the Front Range, Sawatch Range, and San Juan Range of Colorado at latitudes between $36^{\circ} \mathrm{N}$ and $38^{\circ} \mathrm{N}$. These sites extend along the Continental Divide encompassing a wide range of alpine habitats, including meadows, wetlands, dwarf Salix and Dryas patches, and talus fields (Eddleman \& Ward 1984). The soils throughout the range of study sites in Colorado vary considerably, from granitic to limestone-derived. Climatic data for the southern tundra is scare but can be found in Bowman \& Seastedt (2001).

The primary ectomycorrhizal plants of Rocky Mountain alpine areas include dwarf willows Salix reticulata L., $S$. arctica Pall. and rarely $S$. rotundifolia Trautv. and $S$. cascadensis Cockerell. Of shrub willows $S$. glauca L. is more common in the south and $S$. planifolia Pursch is more common in the north; the bog-birch Betula glandulosa Michx. occurs only sporadically in each area (Scott 1995). The mat forming Dryas octopetala L. is host to some ectomycorrhizal fungi in this alpine environment, however no Lactarius species were found in association with this plant.

Specimens were collected from late July to late August and from 1997 through 2011. Selected collections were photographed and described in detail. All were dried and stored either at Montana State University, Bozeman (MONT) or the Institute of Integrative Biology, ETH, Zurich, Switzerland (ZT). Dried material was reconstituted with ethanol and microscopic features examined in Melzer's solution (spores) or $2.5 \%$ potassium hydroxide (cystidia and basidia). For a random sample of 25 basidiospores, length and width was measured, excluding ornamentation and hilar appendix. Maximum height of the ornamentation was also measured, and the pattern of ornamentation described. Length and width of ten pleurocystidia, ten cheilocystidia and five basidia were measured (data not shown). Comparisons were made to known species of Lactarius for identification. Comparisons to species from Finland are included for each species as to occurrence and ecological notes.

\section{Results and discussion}

\section{Lactarius glyciosmus (Fr.) Fr.}

Short diagnosis for Rocky Mountain specimens: this species is recognized by the glaucous, more or less papillate, pale gray-brown to mauve (purple-brown), azonate to slightly zoned pileus, cream to pale orange lamellae, pale yellow to drab orange-brown stipe, watery, clear latex, mild taste and odor of coconut. The spores are 6-9 $\times 5-7 \mu \mathrm{m}$, on average $7.6 \times 6 \mu \mathrm{m}$, broadly ellipsoid to ellipsoid, with ornamentation up to 


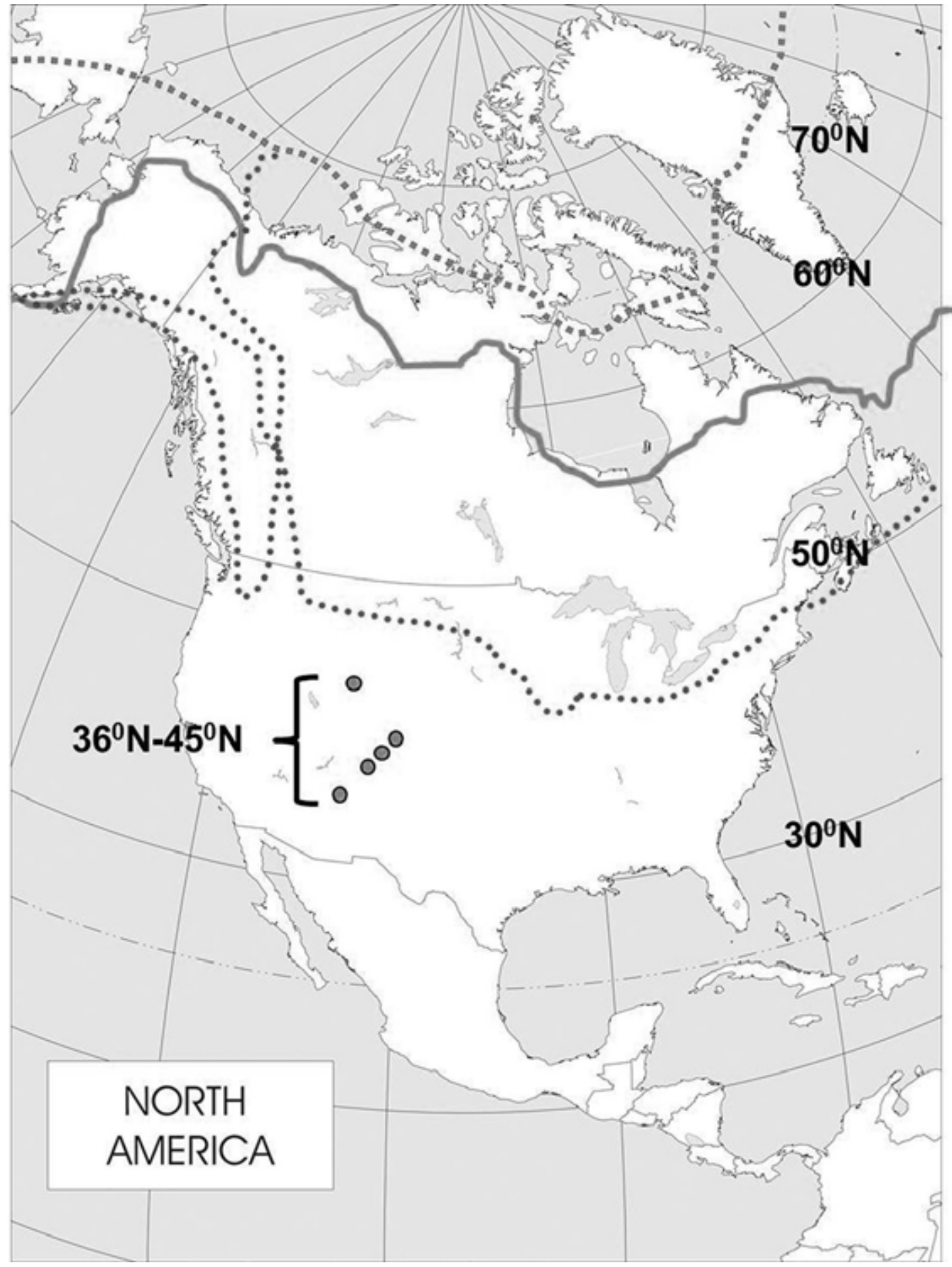

Fig.1. Map of collecting sites in the Rocky Mountain alpine zone. The highest dotted line indicates the boundary of the high Arctic; solid line is the northern limit of trees; lower dotted line is the extent of sheet glaciers; and the dots locate the collecting sites. 


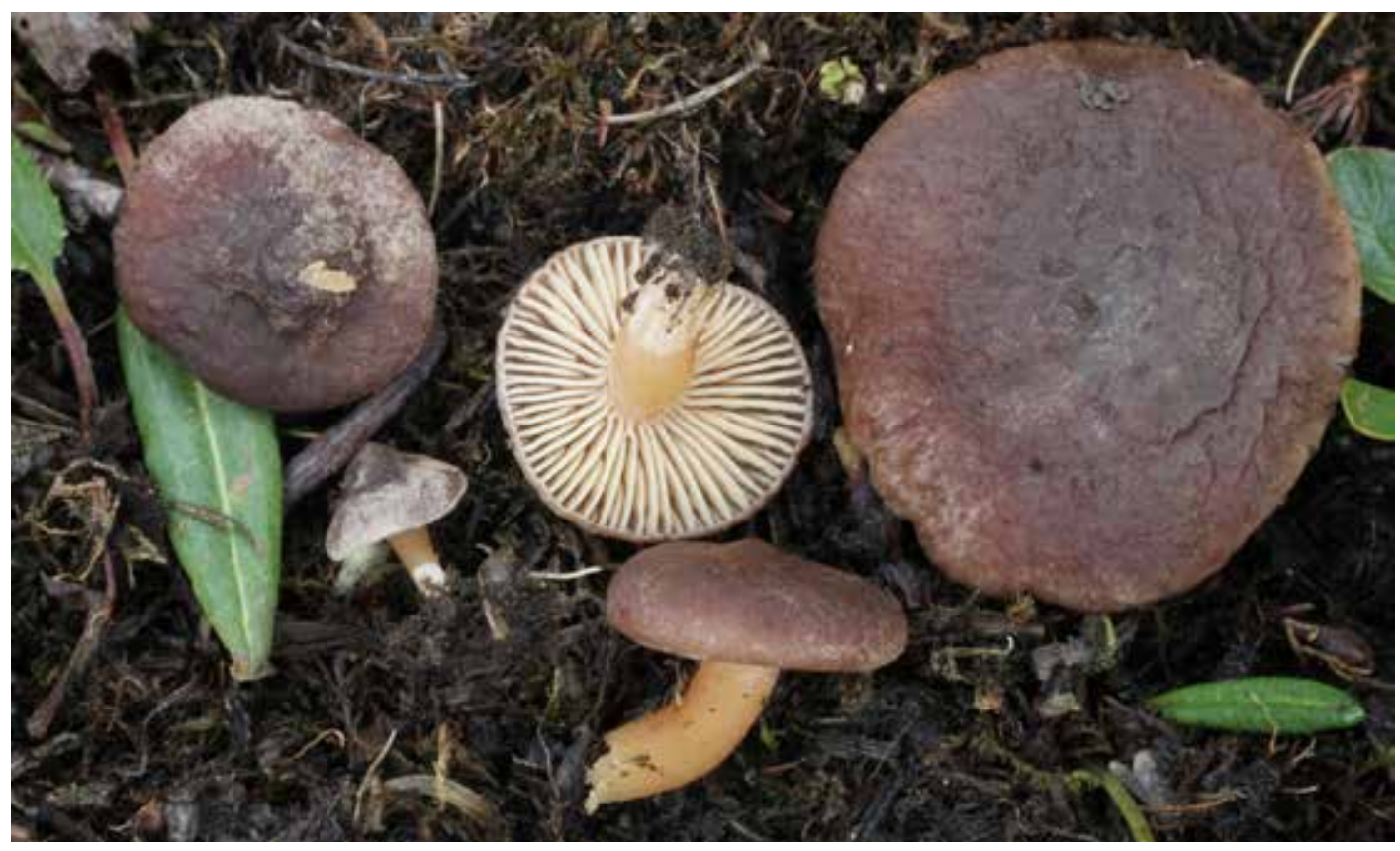

Fig. 2. Beartooth Plateau, Rocky Mountains, USA: latitude $45^{\circ} \mathrm{N}$ and elevation $3300 \mathrm{~m}$. Photo: C. Cripps.

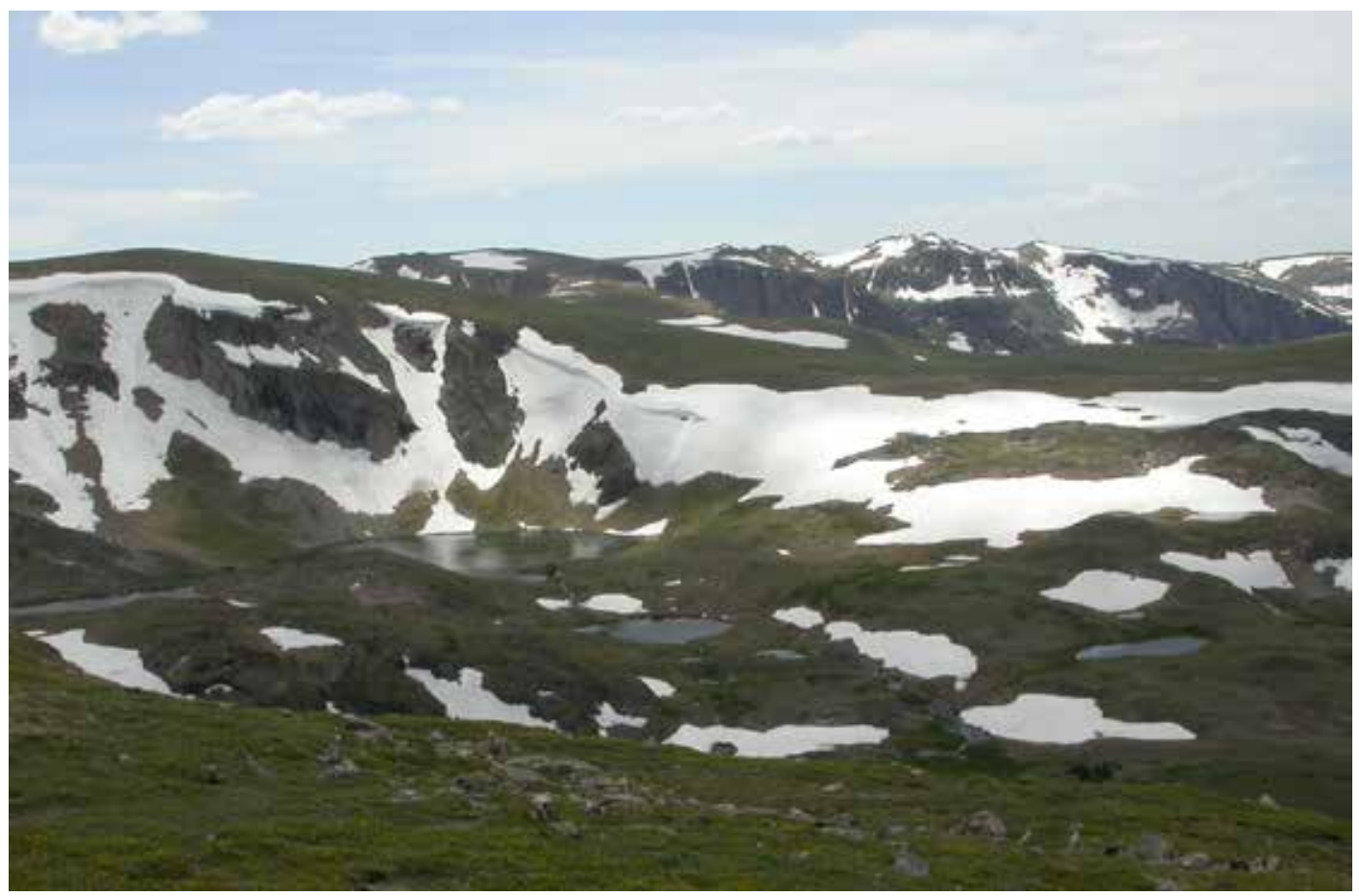

Fig. 3. Example of Lactarius nanus (EB 125) in the Rocky Mountain alpine zone. Photo: C. Cripps. 
$0.5 \mu \mathrm{m}$ high, consisting of elongated warts and ridges forming an incomplete reticulum. It is the only Lactarius species we have found with alpine Betula glandulosa in the Rocky Mountains in this region.

Rocky Mountain ecology: This species occurs in the low alpine zone $(3000 \mathrm{~m})$ on the Beartooth Plateau and also in the alpine-subalpine zone in Colorado with Betula glandulosa. This species is not often encountered as Betula is rare in the alpine zone of the Rocky Mountains south of the Canadian border. It also occurs with bog birch below timberline.

Specimens studied: U.S.A. Colorado. Gunnison County, Cumberland Pass/Quartz Creek, 4.VIII.2001 Cripps 1652 (MONT). Montana. Carbon County, Beartooth Pass, 28.VII.1997 Cripps 1134 (MONT), 10.VIII.1999 Osmundson 269 (MONT), 19.VIII.1999 Cripps 1380 (MONT), 13.VIII.2007 Horak 1273 (ZT). Wyoming. Park County, Beartooth Plateau, 8.VIII.1998 Cripps 1217 (MONT).

Smith \& Hesler (1979) reported this species from subalpine habitats with Betula and Alnus from eastern, central, and western U.S.A. and Canada. For arctic-alpine areas of North America, it has also been reported from Alaska (Laursen \& Ammirati 1982, Geml et al. 2009), the Northwest Territories of arctic Canada (Ohenoja \& Ohenoja 1993, 2010) and Québec (Hutchison et al. 1988) near mixed Betula and Salix spp. It is also known from Greenland (Knudsen \& Borgen 1982, Elborne \& Knudsen 1990, Borgen et al. 2006) and many arctic-alpine areas across the northern hemisphere where it associates primarily with Betula species. This includes Iceland (Halgrímsson 1993), the Alps (Bon 1985, 1998, Graf 1994) and Svalbard (Gulden \& Torkelsen 1996). It is recorded from Finland and other Scandinavian countries with Betula in alpine as well as subtemperate and subarctic areas at low elevations (Kallio \& Kankainen 1964, Korhonen 1984, Ohenoja 1996, Knudsen \& Vesterholt 2012). Subalpine fruiting bodies can be much larger than our alpine specimens and there appears to be large variation in size and coloration for this species (Heilmann-Clausen et al. 1998).

\section{Lactarius lanceolatus O.K. Mill. \& Laursen}

Short diagnosis for Rocky Mountain specimens: this is the only species found to date from our alpine sites with an overall orange brown or red brown fruiting body and pale orange lamellae and stipe. The latex is colorless, the taste mild, and odor faint. Spores are 7-9 $\times 6.5-8 \mu \mathrm{m}$, on average $8.6 \times 7.2 \mu \mathrm{m}$, subglobose to ellipsoid; ornamentation is to $0.5 \mu \mathrm{m}$ high, of fine ridges and isolated warts forming an incomplete reticulum. Cystidia are large and lanceolate, but this may not be completely diagnostic as other species also have long cystidia.

Rocky Mountain ecology: This species is recorded in the alpine zone with willow (primarily $S$. reticulata) from several areas of the Beartooth Plateau at elevations of $3100-3300 \mathrm{~m}$.

Specimens examined: U.S.A. Montana. Carbon County, Beartooth Plateau, Highline Trail, 20.VIII.1999 Cripps 1389 (MONT), 5.VIII.2008 Cripps 2358 (MONT), 1.VIII.1997 Horak 6214 (ZT), 7.VIII.1998 Horak 6412 (ZT); Solifluction Terraces, 13.VIII.2007 Cripps 2319 (MONT).

Lactarius lanceolatus was first described from the Alaskan tundra (Miller et al. 1973) and is also reported from Arctic Canada (Ohenoja \& Ohenoja 1993, 2010) for North America. A taxon with an affinity to this species has been described by Laursen \&Ammirati (1982) from Alaska with Salix and Betula. Lactarius lanceolatus is reported from Greenland (Borgen et al. 2006), Siberia (Knudsen \& Muhkin 1998), Svalbard (Gulden \& Jenssen 1988, Gulden \& Torkelsen 1996) and the Alps (Bon 1998) mostly with Salix species. It may have been reported from other Arctic-alpine areas as L. aurantiacus (Pers. : Fr.) Gray. It is reported from the Enontekiön Lappi area of Finland, Swedish Lappland (Kühner 1975), Northern Norway (Gulden et al. 1985) and other Scandinavian countries (Knudsen \& Vesterholt 2012) at much lower elevations.

Lactarius nanus J. Favre - Fig. 3

Short diagnosis for Rocky Mountain specimens: this species is recognized by the tiny fruiting bodies (typically $1-2 \mathrm{~cm}$ in diam.), moist, mauve 
or brownish cap, well-separated pale orange lamellae, pale orange stipe, clear latex, sharp taste and indistinct odor. Spores are 7-10 × 6-8 $\mu \mathrm{m}$, on average $8.4 \times 6.9 \mu \mathrm{m}$, subglobose to ellipsoid; the ornamentation is to around $0.7 \mu \mathrm{m}$ high, of ridges and warts, connected to form an incomplete reticulum.

Rocky Mountain ecology: this species occurs in wet areas of the alpine zone with dwarf $\mathrm{Sa}$ lix species, primarily $S$. arctica on our sites in both the northern and southern Rocky Mountains from 3100-3840 m.

Specimens examined: U.S.A. Colorado. San Juan County, San Juan Mountains, Black Bear Pass, 11.VIII.2001 Cripps 1716 (MONT), Cinnamon Pass, 27.VIIl.2002 Cripps 1801 (MONT), 11.VIII.2001 Horak 9529 (ZT). Montana. Carbon County, Beartooth Plateau, Highline Trailhead, 8.VIII.1998 Cripps 1221 (MONT), 8.VIII.1998 Horak 6422 (ZT), 21.VIII.1999 Cripps 1403 (MONT), 11.VIII.2012 EB 125 (MONT).

The tiny $L$. nanus occurs with dwarf willows and is easily overlooked because of its small size and drab color. The first report of this species in North America was from the Beartooth Plateau at 3200 m. with Salix reticulata and Salix spp. (Moser \& McKnight 1987). Here we extend its range with the first reports from the southern Rockies still with dwarf willow. It is also reported from arctic Canada with Salix (Ohenoja \& Ohenoja 1993, 2010) and from Greenland (Knudsen \& Borgen 1982, Borgen et al. 2006). It occurs in many other arctic-alpine habitats (Favre 1955, Kühner 1975, Graf 1994, Jamoni 1995, Gulden \& Torkelsen 1996, Gulden et al. 1985, Bon 1998, Corriol 2008, Ronikier 2008). Ronikier (2008) suggests it may be more common in the alpine than the arctic and she presents a complete list of references. It is also reported with $S$. herbacea L. (Gulden et al. 1985, Graf 1994) and S. retusa L. (Kränzlin 2005). This species is known from several Nordic countries and from Finnmark (Ohenoja 1996), and is reported as possibly occurring in Finland (Gulden et al. 1985).

\section{Lactarius repraesentaneus Britzelm.}

Short diagnosis for Rocky Mountain specimens: this robust species has a thick golden brown cap with bearded margin, ochre lamellae and stipe, lilac-staining milk, a mild taste and fruity odor. Spores are 8-11 $\times 6-9 \mu \mathrm{m}$ in diameter, on average $9.2 \times 7.4 \mu \mathrm{m}$, subglobose to ellipsoid; ornamentation is up to $0.7 \mu \mathrm{m}$ high comprised of somewhat broad ridges, forming an incomplete to almost complete reticulum.

Rocky Mountain ecology: This species occurs on our northern and southern Rocky Mountain sites in the alpine zone. The fleshy L. repraesentaneus appears to occur with Salix glauca in alpine areas of Colorado on the more calcareous soils of Cottonwood and Independence Pass (elevations of $3600-3700 \mathrm{~m}$ ). It is also reported from the Beartooth Plateau where S. glauca is present (elevation $3000 \mathrm{~m}$ ). Most areas are near krummholz where conifers are possible. These are the first reports of this species in Rocky Mountain alpine habitats.

Specimens examined: U.S.A. Colorado. Gunnison/Chaffee County, Sawatch Range, Cottonwood Pass, 4.VIII.2001 Cripps 1643 (MONT); Pitkin/Lake County, Sawatch Range, Independence Pass, 14.VIII.2001 Cripps 1747 (MONT), 14.VIII.2001 Horak 9837 (ZT), 15.VIII.2001 Horak 9537 (ZT). Wyoming. Park County, Beartooth Plateau, Frozen Lakes, 21.VIII.1999 Cripps 1394 (MONT). Montana. Carbon County, Beartooth Plateau, East side, Site 1, 21.VIII.2002 Cripps 1971 (MONT), 13.VIII.2007 Cripps 2318 (MONT).

This species is also known to occur in subalpine habitats with conifers, particularly in spruce-fir forests of the northern USA and southern Canada (Hesler \& Smith 1979). This includes Alaska, California, Colorado, Maine, Michigan, New Mexico, New Jersey, Vermont and Ontario. It is also reported from arctic areas of Alaska (Laursen \& Ammirati 1982, Geml et al. 2009) and Greenland (Elborne \& Knudsen 1990, Knudsen \& Borgen 1982, Borgen et al. 2006) in North America. It has been found in subalpine areas of Europe with Betula nana (Heilmann-Clausen et al. 1998). It is known from arctic and alpine habitats in the Alps (Bon 1998) and Iceland (Hal- 
grímsson 1993). In Finland and Scandinavia it occurs in the hemiboreal to subarctic/subalpine and alpine zones (Kallio \& Kankainen 1964, Korhonen 1984, Ohenoja 1996, Knudsen \& Vesterholt 2012) and is reported with Picea and Betula.

\section{Lactarius salicis-reticulatae Kühner}

Short diagnosis for Rocky Mountain specimens: this species is recognized by the viscid pale yellow pileus, pale orange or yellow pink lamellae, pale yellow cream stipe, white latex staining lilac, mild taste and fruity odor. Spores are 9-12 $\times 7.5-10 \mu \mathrm{m}$, on average $10.3 \times 8.3 \mu \mathrm{m}$, subglobose to broadly ellipsoid; ornamentation is up to $0.3 \mu \mathrm{m}$ high, of ridges and irregular warts, not forming a complete reticulum.

Rocky Mountain ecology: it occurs in the alpine zone with Salix species and particularly the dwarf willow $S$. reticulata and the shrubby willow S. planifolia. On the Beartooth Plateau it is at elevations of 3000 to $3200 \mathrm{~m}$ and in the southern Rocky Mountains at elevations of 3600 to $3800 \mathrm{~m}$.

Specimens examined: U.S.A. Colorado. Pitkin/Lake County, Sawatch Range, Independence Pass, 13.VIII.2001 Cripps 1741 (MONT), 13.VIII.2001 Horak 9536 (ZT); San Juan County, San Juan Mountains, Stony Pass, 9.VIII.2001 Cripps 1689 (MONT), 9.VIII.2001 Horak 9792 (ZT), 13.VIII.2011 Barge 0039 (MONT), Cinnamon Pass, 10.VIII.2001 Cripps 1710 (MONT), Black Bear Pass, 11.VIII.2001 Horak 9538 (ZT), Maggie Gulch, 11.VIII.2011 Barge 0036 (MONT); Summit County, Front Range, 14.VIII.1997 Cripps 1155 (MONT), 8.VII.1999 Horak 8094 (ZT). Montana. Carbon County, Beartooth Plateau, Highline Trailhead, 8.VIII.1998 Cripps 1211 (MONT), 8.VIII.2008 Cripps 2378 (MONT); East side, Site 1, 29.VII.1997 Cripps 1136 (MONT), 30.VII.1997 Horak 6099 (ZT), 17.VIII.2011 Cripps 2776 (MONT).

The only report we could find from North America is from Greenland (Borgen et al. 2006); it does not yet appear to be reported from Alaska at least under this name. It may be the same as collections called L. aspideoides Burlingham by
Laursen \& Ammirati (1982) from Alaska and by Hutchison et al. (1988) from Québec. This is the first record for L. salicis-reticulatae in the Rocky Mountains other than a previous brief listing (Cripps \& Horak 2008). It is widespread in arctic-alpine habitats and appears restricted to this zone and is not reported from subalpine forests. It is known from the Alps (Jamoni 1995, Bon 1998) and is typically recorded with dwarf willows, particularly $S$. reticulata and less commonly S. herbacea and Dryas (Jamoni 2008). It occurs in Finland, Norway and Sweden with dwarf and shrubby Salix and Betula (Kühner 1975, Korhonen 1984, Gulden 2005, Knudsen \& Vesterholt 2012).

Acknowledgements: We would like to thank the National Science Foundation for initial support of this project and Egon Horak for certain alpine collections. We also thank Esteri Ohenoja and Anna Ruotsalainen for hosting ISAM 9 at Kevo where we were able to observe arctic-alpine fungi in Finland.

\section{References}

Bon, M. 1985: Quelques nouveaux taxons de la flore mycologique alpine. - Bulletin Trimestriel de la Fédération Mycologique Dauphiné-Savoie 25: 23-30.

Bon, M. 1998: Clé monographique des lactaires alpins. - Bulletin Trimestriel de la Fédération Mycologique Dauphiné-Savoie, Juliet 150: 15-22.

Borgen, T.A., Elborne, S.A. \& Knudsen, H. 2006: A checklist of the Greenland basidiomycetes. In: Boertmann, D. \& Knudsen, H. (eds). Arctic and Alpine Mycology 6. Proceedings of the Sixth International Symposium on Arcto-Alpine Mycology (ISAM 6), Greenland, 11-21 August 2000. - Meddelelser om Grønland, Bioscience 56: 37-59.

Bowman, W.D. \& Seastedt, T.R. (eds) 2001: Structure and Function of an Alpine Ecosystem: Niwot Ridge, Colorado. -337 pp. Oxford Press. New York.

Corriol, G. 2008: Checklist of Pyrenean alpine-stage macrofungi. In: Høiland, K. \& Økland, R.H. (eds). Arctic and Alpine Mycology 7. - Sommerfeltia 31: 29-99.

Cripps, C.L. \& Ammirati, J. (eds) 2010a: Arctic and Alpine Mycology 8. - North American Fungi 5: 1-232.

Cripps, C.L. \& Ammirati, J. 2010b: Eighth International Symposium on Arctic-alpine Mycology (ISAM), Beartooth Plateau, Rocky Mountains, USA 2008. In: Cripps, C.L. \& Ammirati, J.A. (eds). Arctic anc Alpine Mycology 8. Proceedings of the Eighth International Symposium on Arctic-Alpine Mycology (ISAM 8), Beartooth Plateau, Rocky Mountains, U.S.A. August 6-11, 2008. - North American Fungi 5: 1-8.

Cripps, C.L. \& Eddington, L.E. 2005: Distribution of mycorrhizal types among alpine vascular plant families on 
the Beartooth Plateau, Rocky Mountains, USA, in reference to large-scale patterns in Arctic-alpine habitats. - Arctic, Antarctic \& Alpine Research 37: 177-188.

Cripps, C.L. \& Horak, E. 2006: Ecology and worldwide distribution of Arrhenia auriscalpium: a true arcticalpine fungus. In: Boertmann, D. \& Knudsen, H. (eds). Arctic and Alpine Mycology 6. Proceedings of the Sixth International Symposium on Arcto-Alpine Mycology (ISAM 6), Greenland, 11-21 August 2000. - Meddelelser om Grønland, Bioscience 56: 17-24.

Cripps, C.L. \& Horak, E. 2008: Checklist and Ecology of the Agaricales, Russulales and Boletales in the alpine zone of the Rocky Mountains (Colorado, Montana, Wyoming) at 3000-4000 m a.s.l. In: Høiland, K. \& Økland, R.H. (eds). Arctic and Alpine Mycology 7. Sommerfeltia 31: 101-121.

Cripps, C.L. \& Horak, E. 2010: Amanita in the Rocky Mountain alpine zone, USA: New records for A. nivalis and A. groenlandica. In: Cripps, C.L. \& Ammirati, J.A. (eds). Arctic anc Alpine Mycology 8. Proceedings of the Eighth International Symposium on Arctic-Alpine Mycology (ISAM 8), Beartooth Plateau, Rocky Mountains, U.S.A. August 6-11, 2008. - North American Fungi 5: 9-22.

Cripps, C.L., Larsson, E. \& Horak, E. 2010: Subgenus Mallocybe (Inocybe) in the Rocky Mountain alpine zone with molecular reference to European arcticalpine material. In: Cripps, C.L. \& Ammirati, J.A. (eds). Arctic anc Alpine Mycology 8. Proceedings of the Eighth International Symposium on Arctic-Alpine Mycology (ISAM 8), Beartooth Plateau, Rocky Mountains, U.S.A. August 6-11, 2008. - North American Fungi 5: 97-126.

DeSlippe, J.R., Hartmann, M., Mohn, W. \& Simard, S. 2011: Long-term experimental manipulation of climate alters the ectomycorrhizal community of Betula nana in Arctic tundra. - Global Change Biology 17: 1625-1636.

Eddleman, L.E. \& Ward, R.T. 1984: Phytoedaphic relationships in alpine tundra of north-central Colorado, USA. - Arctic, Antarctic \& Alpine Research 16: 343 359.

Elborne, S. \& Knudsen, H. 1990: Larger fungi associated with Betula pubescens in Greenland. In: Boertmann, D. \& Knudsen, H. (eds). Arctic and Alpine Mycology 6. Proceedings of the Sixth International Symposium on Arcto-Alpine Mycology (ISAM 6), Greenland, 1121 August 2000. - Meddelelser om Grønland, Bioscience 33: 77-90.

Favre, J. 1955: Les champignons supérieurs de la zone alpine du Parc Nationale Suisse. - Resultats des recherches scientifiques enterprises au Parc Nationale Suisse 5: 1-212.

Geml, J., Laursen, G.A., Timling, I., McFarland, J., Booth, G., Lennon, N., Nusbaum, C. \& Taylor, D. 2009: Molecular phylogenetic biodiversity assessment of arctic and boreal ectomycorrhizal Lactarius Pers. (Russulales; Basidiomycota) in Alaska, based on soil and sporocarp DNA. - Molecular Ecology 18: 2213-2227.

Geml, J., Timling I., Robinson, C., Lennon, N., Nusbaum, C., Brochmann, C., Noordeloos, M.E. \& Taylor, D.L. 2012: An arctic community of symbiotic fungi as- sembled by long-distance dispersers: phylogenetic diversity of ectomycorrhizal basidiomycetes in Svalbard based on soil and sporocarp DNA. - Journal of Biogeography 39: 74-88.

Graf, F. 1994: Ecology and sociology of macromycetes in snow-beds with Salix herbacea L. in the alpine Valley of Radont (Grisons, Switzerland). - 242 pp. Dissertationes Botanicae. J. Cramer: Berlin.

Gulden, G. 2005: A preliminary guide to the macromycetes in the Finse area, Hardangervidda, Norway. - Draft presented at ISAM VII, Oslo, Norway.

Gulden, G., Jenssen, K.M. \& Stordal, J. 1985: Arctic and Alpine Fungi 1. - 62 pp. Soppkonsulenten. Oslo, Norway.

Gulden, G. \& Jenssen, K.M. 1988: Arctic and alpine fungi 2. -58 pp. Soppkonsulenten. Oslo, Norway.

Gulden, G. \& Torkelsen, A.E. 1996: Fungi I. Basidiomycota: Agaricales, Aphyllophorales, Exobasdiales, Dacrymycetales and Tremellales. In: Elvebakk, A. \& Prestrud, P. (eds). A catalogue of Svalbard plants, fungi, algae and cyanobacteria. - Norsk Polarinstitutt, Skrifter 198: 173-206.

Hallgrímsson, H. 1993: Checklist of Icelandic fungi V: Basidiomycetes. - Natturufra: oistofnun Norourlands: Akureyri Museum of Natural History (unpublished).

Heilmann-Clausen, J., Verbeken, A. \& Vesterholt, J. 1998: The genus Lactarius. -Fungi of Northern Europe 2. 287 pp. Danish Mycological Society.

Hesler, L.R. \& Smith, A.H. 1979: North American species of Lactarius. -841 pp. University of Michigan Press. Ann Arbor.

Hutchison, L., Summerbell, R. \& Malloch, D. 1988: Additions to the Mycota of North America and Québec: Arctic and boreal species from Schefferville, Northern Québec. - Naturaliste canadien 115: 39-56.

Jamoni, P.G. 1995: Russulaceae della zona alpina. - Rivista di Micologia 38, Supplemento: 75-80.

Jamoni, P.G. 2008: Fungi alpine, delle zone alpine superiori e inferiori. - 544 pp. Association Micologica Bresadola, Fondazione centro Studi Micologici. Trento.

Johnson, P.L. \& Billings, W.D. 1962: The alpine vegetation of the Beartooth Plateau in relation to cryopedogenic processes and patterns. - Ecological Monographs 32: 105-135.

Kallio, P. 1982: Aspects of northern Finnish macromycology. - In: Laursen, G.A. \& Ammiriati , J.F (eds). Arctic and Alpine Mycology. The First International Symposium on Arcto-Alpine Mycology: 410-431. University of Washington Press. Seattle.

Kallio, P. \& Kankainen, E. 1964: Notes on the macromycetes of Finnish Lapland and adjacent Finnmark. Reports from the Kevo Subarctic Research Station 1: 178-235.

Knudsen, H. \& Borgen, T. 1982: Russulaceae in Greenland. - In: Laursen, G.A. \& Ammirati, J.F. (eds). Arctic and Alpine Mycology. The First International Symposium on Arcto-Alpine Mycology: 216-244. University of Washington Press. Seattle.

Knudsen, H. \& Mukhin, V.A. 1998: The arctic-alpine agaric element in the Polar Urals and Yamal, Western Siberia. - In: Mukhin, V.A. \& Knudsen, H. (eds): Arctic and alpine Mycology 5. Proceedings of the Fifth International Symposium on Arcto-Alpine Mycology 
(Labytnangi, Russia, August 15-27, 1996): 152-162. Yekaterinburg Publishers. Yekaterinburg, Russia.

Knudsen, H., \& Vesterholt, J., (eds) 2012: Funga Nordica. Agaricoid, boletoid, clavarioid, cyphelloid and gasteroid genera. - 1083 pp. Nordsvamp, Copenhagen.

Korhonen, M. 1984: Suomen rouskut. - 223 pp. Otava. Keuruu, Finland [in Finnish].

Kränzlin, F. 2005: Fungi of Switzerland, Volume 6: Russulaceae. -317 pp. Verlag Mykologia. Luzern.

Kühner, R. 1975: Agaricales de la zone alpine: Lactarius. - Bulletin Trimestriel de la Société Mycologique de France 91: 5-69.

Lange, M. 1955: Macromycetes, part II. Greenland Agaricales. - Meddelelser om Grønland 147: 1-69.

Laursen, G.A. \& Ammirati, J.F. 1982: Lactarii in Alaskan Arctic tundra. - In: Laursen, G.A. \& Ammirati, J.F. (eds): Arctic and Alpine Mycology. The First International Symposium on Arcto-Alpine Mycology: 245281. University of Washington Press. Seattle.

Miller, O.K., Jr. \& Evenson, V. 2001: Observations on the alpine tundra species of Hebeloma in Colorado. - Gilbertson Honorary Volume, Harvard Papers 6: $155-162$.

Miller, O.K., Jr. Laursen, G. \& Murray, B. 1973: Arctic and alpine agarics from Alaska and Canada. - Canadian Journal of Botany 51: 43-49.

Moser, M. \& McKnight, K. 1987 : Fungi (Agaricales, Russulales) from the alpine zone of Yellowstone $\mathrm{Na}$ tional Park and the Beartooth Mountains with special emphasis on Cortinarius. - In: Laursen, G.A, Ammirati, J.F \& Redhead, S. (eds). Arctic and Alpine Myco$\operatorname{logy} 2$ : 299-317. Plenum Press. New York.

Ohenoja, E. 1971: The larger fungi of Svalbard and their ecology. - Report from the Kevo Subarctic Research Station 8: 1221-1247.

Ohenoja, E. 1972: Preliminary note on the botanical research at Rankin Inlet 1971. - Muskox 10: 67.

Ohenoja, E. 1996: A check-list of the larger fungi in Inari Lapland (NE Finland) and in Finnmark (NE Norway). - Kevo Notes 11: 1-44.
Ohenoja, E. \& Ohenoja, M. 1993: Lactarii of the Franklin and Keewatin Districts of the Northwest Territories, Arctic Canada. - In: Petrini, O. \& Laursen, G.A. (eds). Arctic and Alpine Mycology 3-4. Proceedings of the Third and Fourth International Symposium on ArctoAlpine Mycology. - Bibliotheca Mycologica 150: 179-192.

Ohenoja, E. \& Ohenoja, M. 2010: Larger fungi of the Canadian Arctic. - In: Cripps, C.L. \& Ammirati, J.A. (eds). Arctic anc Alpine Mycology 8. Proceedings of the Eighth International Symposium on Arctic-Alpine Mycology (ISAM 8), Beartooth Plateau, Rocky Mountains, U.S.A. August 6-11, 2008. - North American Fungi 5: 85-96.

Osmundson, T.W., Cripps, C.L. \& Mueller, G.M. 2005: Morphological and molecular systematics of Rocky Mountain alpine Laccaria. - Mycologia 97: 949-972.

Ronikier, A. 2008: Contribution to the biogeography of arctic-alpinefungi: first records in the Southern Carpathians (Romania). In: Høiland, K. \& Økland, R.H. (eds). Arctic and Alpine Mycology 7. - Sommerfeltia 31: 191-211.

Scott, R.W. 1995: The alpine flora of the Rocky Mountains. - 901 pp. University of Utah Press. Salt Lake City.

Senn-Irlet, B. 1988: Macromycetes in alpine snow-bed communities - mycocoenological investigations. Acta Botanica Neerlandica 37: 251-263.

Sturm, M., Holmgren, J., McFadden, J., Liston, G., Chapin, F.S. \& Racine, C.H. 2001: Snow-shrub interactions in Arctic tundra: A hypothesis with climatic implications. - Journal of Climate 14: 336-344.

Verbeken, A. 2001: Worldwide systematics of Lactarius: a state of the art. - Micologia e Vegetazione Mediterranea $16: 71-88$. 